\title{
LATENT PERIODS OF SEPTORIA TRITICI BLOTCH ON TEN CULTIVARS OF WHEAT
}

\author{
S.L.H. VILJANEN-ROLLINSON, M.V. MARRONI, \\ R.C. BUTLER, Y. DENG and T. ARMOUR ${ }^{1}$
}

\author{
Crop \& Food Research, Private Bag 4704, Christchurch, New Zealand \\ ${ }^{I}$ Current address: Foundation for Arable Research, PO Box 80, Lincoln, \\ New Zealand
}

Corresponding author: viljanens@crop.cri.nz

\begin{abstract}
A field trial was carried out to determine the length of latent periods of septoria tritici blotch on 10 cultivars of wheat. After artificial inoculation of the flag leaves of all cultivars on a single date, lesions of $S$. tritici showing pycnidia were produced over intervals of 21 to 37 days $\left(273\right.$ to $459^{\circ} \mathrm{C}$ days $)$ after inoculation. Latent periods varied between the cultivars tested, with $\mathrm{cv}$. Domino having the shortest and cv. Regency the longest latent periods. The period of symptom expression for the different cultivars varied from 0 to 11 days $\left(0\right.$ to $122^{\circ} \mathrm{C}$ days $)$, with a mean of $5.0\left(54.4^{\circ} \mathrm{C}\right.$ days). This research provides information that can be used to develop disease models and forecast systems to assist growers with disease control decisions.

Keywords: latent periods, Septoria tritici, winter wheat, disease forecasting.
\end{abstract}

\section{INTRODUCTION}

Septoria tritici blotch (STB), caused by Septoria tritici Roberge in Desmaz. (teleomorph Mycosphaerella graminicola (Fückel) J. Schrot.), is an important foliar disease of autumnsown wheat (Triticum aestivum) crops in New Zealand and other wheat-growing regions of the world. Severe yield losses can occur in crops when the top two or three leaves (flag (final leaf), second and third leaf of wheat plants) become infected. These leaves are important for grain filling, and infected leaves have reduced green leaf area compared with healthy leaves (Shaw \& Royle 1989; Thomas et al. 1989). New Zealand farmers aim to protect these leaves from STB, typically using fungicides applied on three occasions, at full emergence of leaf three, the flag leaf and at flowering.

Considerable effort has been devoted to developing risk-based prediction models to avoid unnecessary applications of fungicides for the control of STB (Thomas et al. 1989; Shtienberg et al. 1990; Verreet 1995; Jørgensen et al. 1999; Moreau \& Maraite 1999). These models have the potential to be used by New Zealand farmers if the models can be validated for New Zealand field conditions.

An understanding of the disease triangle (host-pathogen-environment) is essential when developing disease forecasting models and identifying the conditions under which infection occurs and spreads. Airborne ascospores of $M$. graminicola from stubble of previous wheat crops are the primary inoculum infecting winter wheat crops (Shaw \& Royle 1989). The primary infections produce $S$. tritici pycnidia containing conidia, and as new leaves develop during the growing season, they become infected from the conidia that are either rain-splashed (Shaw \& Royle 1993) or horizontally transferred from infected leaves to the emerging top three leaves (Lovell et al. 2004). This mechanism of dispersal within plants is also an important limitation of disease progress. STB has a long latent period during which time new leaves emerge and often grow away from sources of inoculum during the stem extension phase (Shaw \& Royle 
1989). The length of the latent period depends on cultivar and environmental conditions, such as temperature and leaf wetness, and has been reported to vary from 14 to 21 days at the optimum temperature $\left(15-20^{\circ} \mathrm{C}\right)$ to 40 days at $5^{\circ} \mathrm{C}$ (Eyal et al. 1987; Shaw 1990). Long latent periods also mean that disease control measures may be necessary some time before serious symptoms occur.

The latent period of STB on wheat cultivar Consort at various stages of development has been described previously (Armour et al. 2004). The objective of the present study was to determine the latent period of STB for other commonly grown wheat cultivars following artificial inoculation of flag leaves with S. tritici inoculum under New Zealand field conditions. This research aimed to provide information that can be used to develop disease models and forecast systems that can help New Zealand farmers make STB control decisions.

\section{MATERIALS AND METHODS}

An autumn-sown breeding field experiment established at Lincoln, Canterbury, New Zealand, was used to determine the latent periods of $S$. tritici on the flag leaves of 10 wheat cultivars. There were three replicate plots of each cultivar, laid out in a randomised block design. Each plot was $1 \mathrm{~m}$ long and consisted of six rows, with a susceptible spreader cultivar (Domino) in the outer rows of each plot (as buffers), and two rows each of the two test cultivars in the middle four rows. Five tillers of the test cultivar at the eastern end of each plot were randomly taken and tagged below the flag leaf.

Three isolates of $S$. tritici from the Crop \& Food Research culture collection were selected for artificial inoculation of the wheat cultivars. Production of inoculum was carried out as described by Eyal et al. (1987). Prior to inoculation, the three isolates were mixed together and spore concentration adjusted to $1 \times 10^{7}$ spores $/ \mathrm{ml}$ and a drop of Tween 20 was added to the inoculum mixture. All tagged flag leaves in each plot were inoculated on 10 November 2004 using a cotton bud, and were then covered with a moistened plastic bag overnight to ensure germination of spores.

Flag leaves were first assessed visually for the presence of pycnidia on 29 November 2004 (19 days after inoculation) with further assessments conducted every 2 or 3 days thereafter until all tagged plants had observable pycnidia. The latent period was defined as the time interval from inoculation until pycnidia appeared. This was examined in two ways: (i) time to first appearance of pycnidia (FP) in a plot, and (ii) time until all the leaves in the plot had pycnidia (AP). Symptom expression (SE) was defined as the time interval from FP to AP. Measurements were expressed as days or thermal time with a base temperature of $0^{\circ} \mathrm{C}$, and were analysed using analysis of variance (GenStat $8^{\text {th }}$ Edition). Data are presented here both in tabular and graphic format, for reasons of accuracy and clarity. There were a small number of missing plants that were randomly spread throughout the trial, and therefore the analysis did not need to be adjusted to account for these plants. All inoculated plants became infected.

\section{RESULTS}

The first pycnidia on individual plants in plots were observed 21 to 37 days or 273 to $459^{\circ} \mathrm{C}$ days after inoculation with an overall mean of 27.5 days or $352.8^{\circ} \mathrm{C}$ days. The number of days to all leaves showing pycnidia in the plot (AP) varied from 26 to 37 with a mean of 32.5 days $\left(337\right.$ to $459^{\circ} \mathrm{C}$ days with a mean of $407.2^{\circ} \mathrm{C}$ days). These gave a period of symptom expression (SE) that varied for the different cultivars from 0 to 11 days $\left(0\right.$ to $122^{\circ} \mathrm{C}$ days), with a mean of 5.0 (or $54.4^{\circ} \mathrm{C}$ days).

The number of days to both first pycnidia (FP) and all plants showing pycnidia (AP) varied significantly between cultivars $(\mathrm{P}=0.025$ and $\mathrm{P}=0.009$ respectively). Mean days to FP varied from 22.7 (cv. Domino) to 31.7 days (cv. Regency), and mean days to AP from 27.3 (cv. Domino) to 35.7 (cv. Regency), with no clear groupings of the cultivars (Table 1, Fig. 1a). There were no significant differences in mean SEs for different cultivars $(\mathrm{P}=0.54$, overall mean $=5.0$ days $)$ because of the relatively large variability in SEs. 
Result for days and thermal time were highly correlated $\left(\mathrm{R}^{2}=0.99\right)$ and therefore the results of the analysis of variance of thermal times were similar. There were significant differences between cultivars for thermal time to FP and AP $(\mathrm{P}=0.002$ and $\mathrm{P}=0.011)$, but again there were no significant differences in $\mathrm{SE}(\mathrm{P}=0.574)$. Mean thermal time to FP varied from 294.1 (cv. Domino) to $399.9^{\circ} \mathrm{C}$ days (cv. Regency), and to AP from 351.6 (cv. Domino) to $442.9^{\circ} \mathrm{C}$ days (cv. Regency) with no clear groupings in the cultivars (Fig. 1b).

TABLE 1: Mean number of days and thermal time $\left({ }^{\circ} \mathrm{C}\right.$ days $)$ from inoculation to the appearance of first pycnidia (FP) and times until all the flag leaves showed presence of pycnidia (AP) and symptom expression (SE) for ten cultivars of wheat.

\begin{tabular}{lccccccc}
\hline & \multicolumn{3}{c}{ Days } & & \multicolumn{3}{c}{ Thermal time $\left({ }^{\circ} \mathrm{C}\right.$ days $)$} \\
\cline { 2 - 3 } \cline { 7 - 8 } Cultivar & FP & AP & SE & & FP & AP & SE \\
\hline Domino & 22.7 & 27.3 & 4.7 & & 294 & 352 & 58 \\
Amarok & 24.0 & 30.3 & 6.3 & & 316 & 384 & 68 \\
Equinox & 26.0 & 34.3 & 8.3 & & 337 & 427 & 90 \\
Torlesse & 26.7 & 29.7 & 3.0 & & 345 & 377 & 32 \\
Centaur & 26.7 & 33.3 & 6.7 & & 345 & 417 & 72 \\
Savannah & 28.0 & 30.3 & 2.3 & & 359 & 384 & 25 \\
Weston & 28.3 & 34.3 & 6.0 & & 362 & 427 & 65 \\
Option & 30.3 & 34.3 & 4.0 & & 384 & 427 & 43 \\
Claire & 30.7 & 35.0 & 4.3 & & 386 & 435 & 49 \\
Regency & 31.7 & 35.7 & 4.0 & & 400 & 443 & 43 \\
\hline LSD P=0.05(df=18) & 5.03 & 4.36 & 5.71 & & 55.4 & 48.0 & 63.6 \\
\hline
\end{tabular}
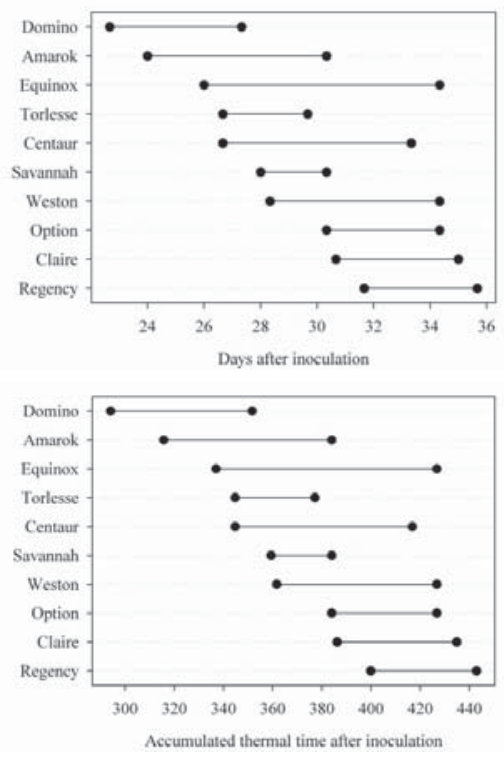

FIGURE 1: Mean septoria tritici blotch symptom expression (SE) in (a) time (days) and (b) thermal time $\left({ }^{\circ} \mathrm{C}\right.$ days) for 10 cultivars of wheat. Each line indicates when plants were producing pycnidia. 


\section{DISCUSSION}

The latent period is one of the components of plant disease resistance that can reduce the rate at which disease epidemics develop. Other important components of resistance are germination and infection efficiency, and rate and duration of spore production. The rate of epidemic development is an important part of disease forecasting systems, especially in systems that incorporate plant disease resistance as a variable.

These results indicated a latent period for STB of 21 (FP) to 37 (AP) days, depending on the cultivar. The cultivar Domino had the shortest latent period and cv. Regency had the longest, measured in terms of FP and AP. This agrees well with several years of field assessments at Lincoln, where the cvs Domino, Torlesse, Savannah, Centaur, Weston and Option have been classified as moderately susceptible or susceptible, and cvs Claire and Regency moderately resistant or resistant to STB (S.L.H. Viljanen-Rollinson, unpubl. data). Latent periods were longer than those reported by Shaw (1990) of $17-20$ days at $16.4^{\circ} \mathrm{C}$ and $21-23$ days at an average temperature of $10.6^{\circ} \mathrm{C}$, and the 14-21 days observed by Eyal et al. (1987). However, our results agree with those reported by Royle et al. (1986) who found incubation periods of 3-5 weeks for $S$. tritici on different winter wheat cultivars. Shaw (1990) suggested that the increase in latent period at higher temperatures may reflect ecological adaptation of the pathogen to the cool summers of the UK. Other important variables that may be relevant in Canterbury are interruptions in leaf wetness and the amount of rainfall, as well as agronomic practices, such as choice of cultivars, use of nitrogen fertiliser, height of cultivars and crop rotation. In addition, plant pathologists have used several different definitions for latent period. In the broadest terms, latent period has been defined as the interval between infection and the first appearance of a sporulating structure (Shearer \& Zadoks 1972). An alternative definition is that the latent period is the time when $50 \%$ of the final number of lesions are visible (e.g. Johnson 1980), but this definition does not describe the range or spread in latency of individual lesions. Defining latency in terms of FP, AP and SE gives an indication of the spread in latency.

Substantial progress has already been made in correlating STB severity with weather variables, of which the amount of rainfall appears to be most commonly used (e.g. Thomas et al. 1989). Other variables used in prediction models include temperature, relative humidity (Moreau \& Maraite 1999) and crop growth stage (Moreau \& Maraite 1994; Verreet 1995). In addition, conditions during the autumn and winter have been found to affect STB severity in the following season, which may facilitate further estimation of disease risk (Parker et al. 1999). However, much less is known about the effects of host resistance on the disease, or the effect that variation in the amount of inoculum may have on subsequent disease progress.

Knowledge of the STB latent periods for different cultivars, together with an understanding of crop phenology, weather conditions and chemical control information will allow development and improvement of disease prediction models that growers can use when scheduling spray applications. Further research into the effect of temperature on latent period, the duration and rate of spore production on host cultivars differing in disease resistance, the presence and quantity of inoculum in the lower crop canopies, crop phenology and chemical efficacy is required before such models can be adapted for application in practical disease prediction in New Zealand conditions.

\section{ACKNOWLEDGEMENTS}

Funding for this research was provided by the New Zealand Foundation for Research, Science and Technology and the Foundation for Arable Research. Cathy Munro sowed and managed the trial.

\section{REFERENCES}

Armour T, Viljanen-Rollinson SLH, Chng SF, Butler RC, Jamieson PD, Zyskowski RF 2004. Examining the latent period of Septoria tritici blotch in a field trial of winter wheat. New Zealand Plant Protection 57: 116-120. 
Eyal Z, Scharen AL, Prescott JM, Ginkel MV 1987. The Septoria diseases of wheat: concepts and methods of disease management. CIMMYT, Mexico City, Mexico. $52 \mathrm{p}$.

Johnson DA 1980. Effect of low temperature on the latent period of slow and fast rusting winter wheat genotypes. Plant Disease 64: 1006-1008.

Jørgensen LN, Secher BJM, Hossy H 1999. Decision support systems featuring Septoria management. In: Lucas JA, Bowyer P, Anderson HM ed. Septoria on cereals: a study of pathosystems. CABI publishing, Wallingford. Pp. 251-262.

Lovell DJ, Parker SR, Hunter T, Welham SJ, Nichols AR 2004. Position of inoculum in the canopy affects the risk of septoria tritici blotch epidemics in winter wheat. Plant Pathology 53:11-21.

Moreau JM, Maraite H 1999. Integration of knowledge on wheat phenology and Septoria tritici epidemiology into a disease risk simulation model validated in Belgium. Aspects of Applied Biology 55: 1-6.

Parker SR, Lovell DJ, Royle DJ, Paveley ND 1999. Analysing epidemics of Septoria tritici for improved estimates of disease risk. In: Lucas JA, Bowyer P, Anderson HM ed. Septoria on cereals: a study of pathosystems. CABI publishing, Wallingford. Pp. 96-107.

Royle DJ, Shaw MW, Cook RJ 1986. Patterns of development of Septoria nodorum and S. tritici in some winter wheat crops in Western Europe 1981-83. Plant Pathology 35: 466-476.

Shaw MW 1990. Effects of temperature, leaf wetness and cultivar on the latent period of Mycosphaerella graminicola on winter wheat. Plant Pathology 39: 255-268.

Shaw MW, Royle DJ 1989. Airborne inoculum as a major source of Septoria tritici (Mycosphaerella graminicola) infections in winter wheat crops in the UK. Plant Pathology 38: 35-43.

Shaw MW, Royle DJ 1993. Factors determining the severity of epidemics of Mycosphaerella graminicola (Septoria tritici) on winter wheat in the UK. Plant Pathology 42: 882-899.

Shearer BJ, Zadoks JC 1972. The latent period of Septoria nodorum in wheat. I. The effect of temperature and moisture treatments under controlled conditions. Netherlands Journal of Plant Pathology 78: 231-241.

Shtienberg D, Dinoor A, Marani AD 1990. Wheat disease control advisory, a decision support system for management of foliar diseases of wheat in Israel. Canadian Journal of Plant Pathology 12: 195-203.

Thomas MR, Cook RJ, King JE 1989. Factors affecting development of Septoria tritici in winter wheat and its effect on yield. Plant Pathology 38: 246-257.

Verreet JA 1995. Principles of integrated pest management: the IPM wheat model. Pflanzenschutz Nachrichten Bayer (English ed.) 48. 307 p. 